\title{
Pemanfaatan Internet pada Matakuliah Ilmu Pendidikan di Fakultas Tarbiyah dan Ilmu Keguruan IAIN Palangka Raya
}

\author{
Jasiah \\ Jurusan Tarbiyah, Fakultas Tarbiyah dan IImu Keguruan, IAIN Palangkaraya \\ Jl. G. Obos Kompleks Islamic Centre, Palangka Raya, Indonesia \\ E-mail: jasiahpalangkaraya@gmail.com
}

\begin{abstract}
The aims this study is the utilization of Internet media by students on science subjects in Faculty of Teacher Training and Science Teaching State Islamic Institute Palangka Raya. The method used in this research is the Mixed Method, which is a merger between quantitative and qualitative methods in a single study. Data collection techniques are observation, interviews and questionnaires. The data analysis technique that is editing, tabulating, analyzing and concluding. The results of this study are based on the results of questionnaires known that 36 students obtained information about the level of utilization of the Internet as a source of learning in the subjects of science education as follows: 8 students (22.22\%) criteria very well, 18 students (50.00\%) criteria, 10 students (27.78\%) criteria good enough, 0 students $(0.00 \%)$ said that the use of the internet as a learning resource study science subjects in the criteria is not good and is not very good. Students use the Internet as a source of learning ,. because with the Internet can assist students in finding information and tasks subjects Education Sciences. If there is no task that many in the college access is facebook, google, yahoo, twitter and youtube.. Factors supporting the use of the Internet as a source of student learning, among others, the demands of the lecturers to fulfill the tasks subjects Education, learning resources available on the internet is more complete, helps the reviewer got the course, making it easier to perform tasks, the existing information more clearly and valid, faster in search of information, resources realy more complete knowledge, the existence of hotspots on campus, which is up to date news / new, lower-cost, easily accessible, curiosity and needs.
\end{abstract}

Keywords: Utilization of Internet, Science Education Course.

\begin{abstract}
Abstrak
Artikel ini terkait dengan pemanfaatan media internet oleh mahasiswa di Fakultas Tarbiyah dan IImu Keguruan IAIN Palangka Raya. Metode penelitian yang digunakan adalah mixmethode yakni gabungan antara metode kuantitatif dan kualitatif. Data dikumpulkan melalui observasi, wawancara, dan kuesioner. Teknik analisis data mengikuti prosedur editing, tabulating, analyzing, dan concluding. Berdasarkan hasil kuesioner, dari 36 mahasiswa yang menggunakan internet sebagai sumber belajar pada matakuliah Ilmu Pendidikan ada 8 mahasiswa (22,22\%) yang mengatakan bahwa penggunaan internet menjadi sumber belajar pada matakuliah IImu Pendidikan adalah sangat baik, 18 mahasiswa (50,00\%) pada kategori baik, dan 10 mahasiswa (27,78\%) cukup baik. Mahasiswa menggunakan internet sebagai sumber belajar karena internet dapat membantu mahasiswa dalam mencari informasi dan tugas-tugas pada matakuliah Ilmu Pendidikan. Apabila tidak ada tugas, sebagian besar mahasiswa menggunakan internet untuk mengakses facebook, google, yahoo, trwitter, dan youtube. Faktor-faktor yang mendukung penggunaan internet sebagai sumber belajar antaralain tuntutan para dosen terkait tugas matakuliah IImu Pendidikan, informasi yang tersedia di internet relatif lebih lengkap sehingga membantu dalam penyelesaian tugas,
\end{abstract}


informasi yang ada lebih jelas dan valid, lebih cepat dalam memperoleh informasi, sumber informasi yang lengkap, keberadaan hotspot di kampus, berisi informasi yang terbaru, biaya yang tidak mahal, mudah diakses, rasa ingin tau, serta karena kebutuhan.

Kata Kunci: Pemanfaatan internet, Matakuliah IImu pendidikan.

\section{Pendahuluan}

Pendidikan di lakukan untuk mewujudkan masyarakat yang sejahtera, baik dari segi kualitas maupun kuantitas pengetahuan yang di milikinya. Keberhasilan pendidikan bermutu sesuai harapan pemerintah di tentukan oleh proses pendidikan yang di alami oleh peserta didik, begitu juga dengan kompetensi pengajar yang tepat. Adanya dukungan sistem sarana dan prasarana serta media pembelajaran yang menopang proses belajar mengajar sangat penting untuk di berikan kepada peserta didik, karena hal ini menyangkut aspek perkembangan kognitif peserta didik sebagai objek utama dalam kegiatan belajar mengajar setiap hari.

Pembelajaran adalah proses interaksi peserta didik dengan guru dan sumber belajar pada suatu lingkungan belajar. Di mana proses pembelajaran tersebut perlu direncanakan, dilaksanakan, dinilai, dan diawasi agar terlaksana secara efektif dan efesien. Proses pembelajaran pada setiap satuan pendidikan harus interaktif, inspiratif, menyenangkan, menantang, dan memotivasi peserta didik untuk berpartisipasi secara aktif, serta memberikan ruang yang cukup bagi prakarya, dan perkembangan fisik serta psikologis peserta didik. Ada beberapa hal yang perlu di perhatikan dalam pembelajaran: (1) Apa yang diajarkan; berkaitan dengan tujuan dan materi yang diajarkan, (2) Bagaimana cara mengajarnya; menyangkut metode mengajar dan alat peraga apa yang yang akan di gunakan dalam pembelajaran, (3) Bagaimana cara mengetahui bahwa yang di ajarkan dapat dipahami mahasiswa; berkaitan dengan cara mengevaluasi terhadap materi yang telah di ajarkan.

Proses pembelajaran dalam pendidikan di era abad-21, menuntut satu strategi tertentu yang berbeda dengan di masa lain. Dengan perkembangan global yang terjadi menjelang masuknya abad-21, proses pembelajaran bukan hanya dalam bentuk pemrosesan informasi, akan tetapi harus dikembangkan sedemikian rupa sehingga mampu mengembangkan sumber daya manusia kreatif yang adaptif terhadap tuntutan yang berkembang. ${ }^{1}$ Teknologi informasi berkembang pesat melebihi bidang lainnya. Faktor penentunya adalah globalisasi informasi, yaitu penyebaran akses dan produksi informasi ke seluruh dunia. Informasi dapat diakses oleh siapa saja dan di mana saja. Informasi begitu mudah diperoleh baik lewat media massa,

1 Mohammad H Surya, 'Tantangan Dan Problema Pendidikan Memasuki Milenium Ketiga', Ilmiah Wahana, 2010, 4. 
elektronik, maupun melalui jaringan teknologi internet. Menurut Ghufron terpajangnya bahan informasi lewat media massa, baik elektronik maupun cetak, berpengaruh sangat positif terhadap pembaca ${ }^{2}$. Selain muatannya yang mungkin bermanfaat bagi pembaca, media informasi tersebut juga memberikan pajangan yang berdampak positif terhadap akuisisi bahasa para pembaca. Sebagaimana yang dikemukakan oleh Idris, diakui bahwa internet merupakan jaringan informasi, komunikasi, penyelidikan, dan berbagai sumber yang tidak terhingga banyaknya yang dapat digunakan untuk membantu mahasiswa menghasilkan skripsi, kerja proyek, dan sebagainya ${ }^{3}$. Internet sebagai alat untuk mencapai informasi dalam skala global. Mahasiswa kini dapat memperoleh informasi yang lebih daripada apa yang terdapat dalam buku teks dengan mencari dan mengakses semua website di seluruh dunia. dapat dicontohkan seperti negara Jepang dan Singapore yang miskin sumber daya alamnya, tetapi tinggi kualitas pembelajarannya, makapembangunan di negera inirelatif sangat maju. Internet sebagai media Media merupakan sarana penyalur informasi di dalam proses belajar mengajar. Media juga dapat diartikan sebagai segala sesuatu yang dapat digunakan untuk menyalurkan pesan dari pengirim ke penerima sehingga dapat merangsang pikiran, perasaan, perhatian dan minat serta perhatian mahasiswa sedemikian rupa sehingga proses belajar terjadi.

Internet sebagai media pembelajaran merupakan wahana penyampaian isi pesan pembelajaran pada pebelajar. Secara umum media mempunyai kegunaan untuk mengatasi berbagai hambatan-hambatan komunikasi, keterbatasan ruang kelas, sikap pebelajar memberikan gambaran bahwa penekanan dan tuntutan pembelajaran yang semakin cepat, efektif dan efesien tidak dapat dihindari lagi. Pembelajaran yang cepat, efektif dan efesien ini juga merupakan tujuan pembelajaran yang menekankan pada penguasaan secara tuntas (learning to mastery atau mastery learning). Untuk mengatasi hal tersebut, salah satu teknologi jaringan belajar yang oleh Henich, Molenda, Russell, \& Smaldino (2002, 2005) disebut sebagai online technology. Teknologi ini menawarkan suatu alternatif yang memungkinkan pebelajar dapat mengakses sendiri mteri atau bahan yang dibelajarkan (selfcontained materials) yaitu dalam bentuk online learning.

2 Parji, Strategi Pembelajaran Pendidikan Moral Pada Era Teknologi Informasi (Madiun, 2011), 102.

${ }^{3}$ Fazilah Idris, 'Jurnal Bahasa (Pembelajaran Bahasa)', Makalah Internet Dan Belajar, 2010, 1-2. 
Pembelajaran melalui sistem jaringan online ini sebagaimana dikemukakan oleh Clark \& Mayor mencakup lima hal penting yaitu (1) isi yang disajikan memiliki relevansi dengan tujuan khusus pembelajaran yang ingin dicapai. (2) menggunakan metode-metode pembelajaran melalui contoh-contoh dan latihan-latihan untuk membantu belajar pebelajar, (3) menggunakan media seperti gambar-gambar dan kata-kata untuk menyajikan isi dan metode dan (4) mengembangkan dan membangun pengetahuan dan keterampilan belajar sesuai dengan tujuan individu dan peningkatan organisasi.

Proses pemanfaatan media internet sangat dimungkinkan dapat memfleksibilitaskan pembelajaran sehingga pebelajar dapat lebih memperoleh pengetahuan lebih banyak. Tingkat fleksibilatas itulah yang membuat internet dapat dimanfaatkan sebagai media pembelajaran dapat diaplikasikan untuk semua pendidikan dan keilmuan.

Kendala-kendala yang dihadapi mata kuliah ilmu pendidikan adalah sebagai berikut: (1) Penguasaan mahasiswa terhadap materi serta kompetensi yang diharapkan dalam proses pembelajaran, masih tergolong lemah. Hal ini disebabkan cakupan materi yang tergolong luas dan mahasiswa dituntut untuk mampu mengaalisis dan mensistensis materi. Berdasarkan pengalaman yang dialami, proses menganalisis dan mensistensis suatu materi membutuhkan waktu yang cukup banyak karena terkait erat dengan banyaknya literatur dan pengetahuan yang harus dimiliki seseorang. (2) Variasi media pembelajaran yang kurang, sehingga membuat mahasmiswa menjadi cepat bosan dengan metode pembelajaran yang diberikan dosen. (3) Karakteristik materi yang harus banyak menjabarkan secara detil tentang pendidikan sangat dimungkinkan untuk sering memberikan studi kasus. Berdasarkan hal-hal tersebutlah diperlukan media dimana pebelajar dapat mengakses secara mudah, cepat dan efesien dalam proses pencarian.

Berdasarkan uraian latar belakang diatas, maka rumusan masalah dalam penelitian ini, sebagai berikut:

1. Bagaimana pemanfaatan internet pada mata kuliah Ilmu Pendidikan Jurusan Tarbiyah Fakultas Tarbiyah dan Ilmu Keguruan IAIN Palangka Raya.

2. Apa alasan mahasiswa Jurusan Tarbiyah FTIK IAIN Palangka Raya memanfaatkan internet?

3. Apa faktor pendukung dan penghambat pemanfaatan internet pada mata kuliah Ilmu Pendidikan Jurusan Tarbiyah Fakultas Tarbiyah dan Ilmu Keguruan IAIN Palangka Raya. 


\section{Kerangka Teoretis}

\section{Internet dan Manfaatnya Sebagai Media Pembelajaran IImu Pendidikan}

Media merupakan wadah dari pesan yang oleh sumber atau penyalurnya ingin diteruskan kepada sasaran atau penerima pesan tersebut. Materi yang ingin disampaikan adalah pesan pembelajaran, dan bahwa tujuan yang ingin dicapai adalah terjadinya proses belajar. Yang ingin disampaikan di sini adalah bahwa proses kegiatan belajar/mengajar adalah suatu proses komunikasi. Dengan kata lain, kegiatan belajar melalui media terjadi bila ada komunikasi antara penerima pesan dengan sumber lewat media tersebut.

Menurut Oetomo, internet atau international network adalah sebuah jaringan komputer yang sangat besar yang terdiri dari jaringan-jaringan kecil yang saling terhubung yang menjangkau seluruh dunia. ${ }^{4}$ Interconnection Networking atau singkatannya lebih dikenal sebagai Internet diartikan oleh Randall dan Latulipe, sebagai suatu jaringan global yang terdapat di dalam jaringan komputer. ${ }^{5}$ Berdasarkan pendapat tersebut maka peneliti menegaskan bahwa, internet adalah suatu jaringan yang bersifat global. Tidak pandang di mana dan siapa saja bisa berkomunikasi dan mengakses berbagai informasi dalam segala bidang.

Internet merupakan sebuah sistem teknologi komunikasi yang bisa menghubungkan antar satu komputer dengan komputer lainnya sehingga menjadi sebuah jaringan, jaringan ini mencakup seluruh dunia. Bisa kita bayangkan ada berapa banyak komputer di seluruh dunia, dan semua komputer tersebut bisa saling terhubung melalui suatu sistem jaringan yang dinamakan internet. Ada standar tertentu yang lalu menjadi sebuah aturan baku supaya satu komputer bisa berkomunikasi dengan komputer lain yang ada pada jaringan internet, yaitu dengan adanya protokol TCP/IP. Protokol ini bisa kita ibaratkan sebagai sebuah pintu pada rumah.

Oetomo mengatakan bahwa era internet terus bergulir sehingga makin banyak orang terdorong untuk mengakses internet baik untuk keperluan bisnis, surat menyurat maupun pendidikan, mulai dari anak-anak hingga orang dewasa. Internet kini mulai dirasakan sebagai suatu kebutuhan pokok

4 Budi Oetomo Dharma Sutedjo, E-Education Konsep, Teknologi Dan Aplikasi Internet Pendidikan (Yogyakarta: Andi Yogyakarta, 2002), 3.

${ }^{5}$ Nafisah Binti Murshid, 'Hubungan Penggunaan Media Komputer Berbasis Internet Sebagai Sumber Belajar Dengan Hasil Belajar Mahasiswa Malaysia Di Universitas Negeri Semarang Tahun Akademik 2000/2001' (Jurusan Kurikulum Teknologi Pendidikan Fakultas Ilmu Pendidikan Universitas Negeri Semarang, 2001), 2.

Al-Khwarizmi - 69 
untuk memperoleh informasi yang baru dan lengkap. ${ }^{6}$ Menurut Kayo, Mori, dan Takano mengatakan bahwa keistimewaan yang terdapat dalam internet pertama adalah kebebasan internet. Internet memberi pengguna kuasa untuk memberi dan menerima informasi dengan bebas. Kedua, internet lebih dinamik, mengikuti perkembagan waktu. Kebanyakan informasi dalam internet kebanyakan ialah informasi paling baru jika dibandingkan dengan informasi dalam bahan bercetak. Ketiga, internet bersifat interaktif. Melalui internet, pengguna dapat berinteraksi dengan pengguna lain di dunia ini setiap saat. ${ }^{7}$

Penggunaan internet boleh ditekankan kepada pembelajaran yang melibatkan ketercapaian kepada informasi. Internet mengandung kumpulan data dan informasi yang banyak berkaitan dengan berbagai topik dan cara berkomunikasi melalui kemudahan-kemudahan yang tersedia. Internet memberikan layanan yang meliputi, World Wide Web (WWw), E-Mail (surat elektronik), Internet Relay Chat (IRC), Mailing List, Newsgroup dan File Transfer Protocol (FTP).

Setiap aplikasi dari fasilitas-fasilitas yang tersedia di dalam jaringan internet mempunyai fungsinya masing-masing. Melihat dari fungsi-fungsi tersebut, World Wide Web ( $W w W$ ) adalah proses mengambil, memformat dan menampilkan informasi (termasuk teks, audio, grafik dan video). Terdapat sekitar 2800 jurnal yang secara elektronik dapat diakses dengan menggunakan fasilitas Web ini, termasuk kemampuan untuk mengakses data dari berbagai perpustakaan yang terdapat diseluruh dunia. E-Mail atau surat elektronik berkaitan langsung dengan pribadi tanpa mengenal batas waktu, ruang (tempat, negara, kota), birokrasi. Chatting adalah komunikasi interaktif antara pengguna internet apabila memasuki server-server IRC (Internet Relay Chat) tertentu, yaitu aplikasi yang memungkinkan pengguna berkomunikasi secara real-time dengan pengguna lain di internet. Mailing List (daftar alamat surat) adalah diskusi secara elektronik yang menggunakan fasilitas E-Mail, dapat digunakan untuk kelas-kelas jarak jauh.

\section{Pemanfaatan Internet oleh Mahasiswa}

Dunia pendidikan terus bergerak secara dinamis, khususnya untuk menciptakan media, metode dan materi pendidikan yang semakin interaktif dan komprehensif. Berbagai metode itu tentu saja tidak lepas dari peran media sebagai sarana untuk penyampaiannya, dan salah satunya adalah

\footnotetext{
${ }^{6}$ Sutedjo, E-Education Konsep, Teknologi Dan Aplikasi Internet Pendidikan, 52.

7 'Pengertian Jaringan Internet', 2016, www.seputar.com.2016/02/9-pengertianjaringan-internet-menurut-para-ahli.html.
} 
internet. Tanpa menggunakan media itu, maka proses belajar mengajar tidak dapat berkembang dengan baik.

Menurut Sadiman menyatakan bahwa perubahan dan perkembangan yang berlaku dengan cepat, memerlukan penyediaan sumber belajar yang aktual, kaya informasi dan mudah terjangkau. Internet adalah teknologi yang telah memberikan landasan kuat bagi terciptanya lingkungan belajar yang kaya dan luwes, serta mampu memenuhi pendidikan dan latihan. Internet adalah jaringan dari jaringan, sebagaimana jaringan telepon yang mengkomunikasikan suara, internet mengkomunikasikan data. ${ }^{8}$

Internet mengandung kumpulan data dan informasi yang banyak berkaitan dengan berbagai topik. Dalam pencarian item informasi tertentu, informasi dapat dibagi menjadi tiga kategori mudah. (1) kategori informasi yang sesuai, yaitu lembaran informasi yang memang dikehendaki. (2) kategori informasi yang memang tidak diperlukan langsung, yang merujuk kepada kumpulan informasi yang tidak ada nilai dan tidak ada kaitan langsung dengan keperluan, (3) informasi yang masih samar-samar, merupakan kumpulan informasi yang perlu diperdebatkan dan dibincangkan sama ada ia sesuai atau sebaliknya.

Internet memungkinkan orang berbicara; setiap orang mempunyai pendapat, dan semua pendapat itu tampaknya bermuara pada Internet. Internet di sini berperan sebagai sebuah laporan pelanggan berkesinambungan, dengan setiap orang secara tidak henti-hentinya menyumbangkan pandangan, pengalaman, rekomendasi, dan peringatan. Aplikasi komunikasi internet untuk meminta bantuan dari ribuan orang, menyiarkan pengumuman mengenai suatu peristiwa atau suatu layanan baru, menawarkan analisis mengenai suatu keadaan, atau hanyalah melibatkan diri dalam suatu kelompok minat tertentu. Internet adalah perkakas sempurna untuk menyiagakan dan mengumpulkan sejumlah besar orang secara elektronis. Informasi mengenai suatu peristiwa tertentu dapat ditransmisikan secara langsung sehingga membuatnya menjadi suatu piranti meriah yang sangat efektif. Banyak sekali forum yang tersedia untuk tujuan istimewa ini mengumumkan berita terakhir mengenai suatu peristiwa (http://www.intracomm.com).

8 Arief S Sadirman, Media Pendidikan: Pengertian, Pengembangan Dan Pemanfaatannya (Jakarta: Raja Grafindo Persada, 1993), 94. 


\section{Metode Penelitian}

Metode yang digunakan dalam penilitian ini adalah Mixed Method, yaitu penggabungan antara metode kuantitatif dan kualitatif dalam satu penelitian. Mixed method (metode gabungan: kulitatif-kuantitatif) adalah metode dengan menggunakan gabungan pada prosedur penelitian, dimana salah satu metode lebih dominan terhadap metode yang lain. Metode yang kurang dominan hanya diposisikan sebagai metode pelengkap sebagai data tambahan. Adapun metode yang lebih dominan dalam penelitian ini adalah metode kualitatif dan sebagai metode pelengkapnya adalah metode kuantitatif. Teknik pengumpulan data yaitu observasi, wawancara dan angket. Teknik analisis data yaitu editing, tabulating, coding dan concluding.

\section{Pemahaman Mahasiswa tentang Konsep Internet sebagai Sumber Belajar Matakuliah Ilmu Pendidikan}

Berdasarkan jawaban angket pada indikator pemahaman serta sikap tentang konsep internet sebagai sumber belajar mata kuliah ilmu pendidikan dari masing-masing mahasiswa diperoleh hasil seperti terangkum pada Tabel 1 berikut:

Tabel 1 Pemahaman Mahasiswa tentang Konsep Internet Sebagai Sumber

Belajar Matakuliah ilmu pendidikan

\begin{tabular}{|c|c|l|c|c|}
\hline No & Rentang Skor & \multicolumn{1}{|c|}{ Kategori } & Frekuensi & Persentase \\
\hline 1. & $13-15$ & Sangat baik & 12 & $33.33 \%$ \\
\hline 2. & $11-12$ & Baik & 19 & $52.78 \%$ \\
\hline 3. & $8-10$ & Cukup baik & 5 & $13.89 \%$ \\
\hline 4. & $6-7$ & Tidak baik & 0 & $0.00 \%$ \\
\hline 5. & $3-5$ & Sangat tidak baik & 0 & $0.00 \%$ \\
\hline \multicolumn{2}{|c|}{ Jumlah } & 36 & $100.00 \%$ \\
\hline
\end{tabular}

Sumber data: Angket

Berdasarkan Tabel 1 dapat diketahui dari 36 mahasiswa diperoleh keterangan pemahaman tentang konsep internet sebagai sumber belajar mata kuliah ilmu pendidikan sebagai berikut: 12 mahasiswa $(33,33 \%)$ mengatakan bahwa pemahaman serta sikap mahasiswa tentang konsep internet sebagai sumber belajar mata kuliah ilmu pendidikan dalam kategori sangat baik, 19 mahasiswa (52,78\%) mengatakan bahwa pemahaman serta sikap mahasiswa tentang konsep internet sebagai sumber belajar mata kuliah ilmu pendidikan dalam kategori baik, 5 mahasiswa (13,89\%) mengatakan bahwa pemahaman serta sikap mahasiswa tentang konsep internet sebagai sumber belajar mata kuliah ilmu pendidikan dalam kategori cukup baik, 0 mahasiswa (0,00\%) mengatakan bahwa pemahaman mahasiswa tentang konsep internet sebagai sumber belajar mata kuliah ilmu 
pendidikan dalam kategori tidak baik dan sangat tidak baik. Hasil ini menunjukkan bahwa secara umum mahasiswa telah mampu mengoperasikan internet dan menggunakannya untuk tujuan belajar dengan baik.

\section{Ketersediaan dan Ketepatan Fungsi Internet sebagai Sumber Belajar}

Berdasarkan jawaban angket pada indikator ketersediaan internet sebagai sumber belajar mata kuliah ilmu pendidikan dari masing-masing mahasiswa diperoleh hasil sebagai berikut:

Tabel 2. Ketersediaan Internet Sebagai Sumber Belajar Mata kuliah Ilmu Pendidikan

\begin{tabular}{|c|c|l|c|c|}
\hline No & Rentang Skor & \multicolumn{1}{c|}{ Kategori } & Frekuensi & Persentase \\
\hline 1. & $17-20$ & Sangat baik & 11 & $30.56 \%$ \\
\hline 2. & $14-16$ & Baik & 18 & $50.00 \%$ \\
\hline 3. & $11-13$ & Cukup baik & 7 & $19.44 \%$ \\
\hline 4. & $8-10$ & Tidak baik & 0 & $0.00 \%$ \\
\hline 5. & $4-7$ & Sangat tidak baik & 0 & $0.00 \%$ \\
\hline \multicolumn{3}{|c|}{ Jumlah } & 36 & $100.00 \%$ \\
\hline
\end{tabular}

Sumber data: Angket

Berdasarkan tabel 2 dapat diketahui dari 36 mahasiswa diperoleh keterangan tentang ketersediaan internet sebagai sumber belajar mata kuliah ilmu pendidikan sebagai berikut: 11 mahasiswa (30,56\%) mengatakan bahwa ketersediaan internet sebagai sumber belajar mata kuliah ilmu pendidikan termasuk dalam kriteria sangat baik, 18 mahasiswa $(50,00 \%)$ mengatakan bahwa ketersediaan internet sebagai sumber belajar mata kuliah ilmu pendidikan termasuk dalam kriteria baik, 7 mahasiswa $(19,44 \%)$ mengatakan bahwa ketersediaan internet sebagai sumber belajar mata kuliah ilmu pendidikan termasuk dalam kriteria cukup baik, 0 mahasiswa $(0,00 \%)$ mengatakan bahwa ketersediaan internet sebagai sumber belajar mata kuliah ilmu pendidikan termasuk dalam kriteria tidak baik dan sangat tidak baik. Hasil ini menunjukkan bahwa secara umum fasilitas internet di kampus maupun di lingkungan tempat tinggal mahasiswa telah tersedia secara memadai untuk tujuan kegiatan belajar mahasiswa.

Berdasarkan jawaban angket pada indikator ketepatan fungsi internet sebagai sumber belajar mata kuliah ilmu pendidikan dari masing-masing mahasiswa diperoleh hasil seperti terangkum pada Tabel 3 berikut: 
Tabel 3. Ketepatan Fungsi Internet Sebagai Sumber Belajar Mata Kuliah Ilmu Pendidikan

\begin{tabular}{|c|c|l|c|c|}
\hline No & Rentang Skor & \multicolumn{1}{c|}{ Kategori } & Frekuensi & Persentase \\
\hline 1. & $22-25$ & Sangat baik & 13 & $36.11 \%$ \\
\hline 2. & $17-21$ & Baik & 20 & $55.56 \%$ \\
\hline 3. & $14-17$ & Cukup baik & 3 & $8.33 \%$ \\
\hline 4. & $10-13$ & Tidak baik & 0 & $0.00 \%$ \\
\hline 5. & $5-9$ & Sangat tidak baik & 0 & $0.00 \%$ \\
\hline \multicolumn{5}{|c|}{ Jumlah } \\
\hline
\end{tabular}

Sumber data: Angket

Berdasarkan Tabel 3 dapat diketahui dari 36 mahasiswa diperoleh tentang ketepatan fungsi internet sebagai sumber belajar mata kuliah ilmu pendidikan sebagai berikut : 13 mahasiswa (36,11\%) mengatakan bahwa ketepatan fungsi internet sebagai sumber belajar mata kuliah ilmu pendidikan termasuk dalam kriteria sangat baik, 20 mahasiswa $(55,56 \%)$ mengatakan bahwa ketepatan fungsi internet sebagai sumber belajar mata kuliah ilmu pendidikan termasuk dalam kriteria baik, 3 mahasiswa $(8,33 \%)$ mengatakan bahwa ketepatan fungsi internet sebagai sumber belajar mata kuliah ilmu pendidikan termasuk dalam kriteria cukup baik, 0 mahasiswa $(0,00 \%)$ mengatakan bahwa ketepatan fungsi internet sebagai sumber belajar mata kuliah ilmu pendidikan termasuk dalam kriteria tidak baik dan sangat tidak baik. Hasil ini menunjukkan bahwa secara umum mahasiswa memberikan penilaian bahwa internet dapat digunakan untuk sumber belajar mata kuliah ilmu pendidikan.

\section{Intensitas Mahasiswa Mengakses Informasi dari Internet}

Berdasarkan jawaban angket pada indikator intensitas mengakses informasi dari internet oleh masing-masing mahasiswa diperoleh hasil seperti terangkum pada Tabel 4 berikut:

Tabel 4 Intensitas Mahasiswa tentang Mengakses Informasi dari Internet

\begin{tabular}{|c|c|l|c|c|}
\hline No & Rentang Skor & \multicolumn{1}{c|}{ Kategori } & Frekuensi & Persentase \\
\hline 1. & $17-20$ & Sangat baik & 2 & $5.56 \%$ \\
\hline 2. & $14-16$ & Baik & 8 & $22.22 \%$ \\
\hline 3. & $11-13$ & Cukup baik & 19 & $52.78 \%$ \\
\hline 4. & $8-10$ & Tidak baik & 7 & $19.44 \%$ \\
\hline 5. & $4-7$ & Sangat tidak baik & 0 & $0.00 \%$ \\
\hline \multicolumn{5}{|c|}{ Jumlah } \\
\hline
\end{tabular}

Sumber data: Angket 
Berdasarkan Tabel 4 dapat diketahui dari 36 mahasiswa diperoleh keterangan tentang intensitas mahasiswa tentang mengakses informasi dari internet sebagai berikut: 2 mahasiswa (5,56\%) mengatakan bahwa intensitas tentang mengakses informasi dari internet dalam kriteria sangat baik, 8 mahasiswa (22,22\%) mengatakan bahwa intensitas tentang mengakses informasi dari internet dalam kriteria baik, 19 mahasiswa (52,78\%) mengatakan bahwa intensitas tentang mengakses informasi dari internet dalam kriteria cukup baik, 7 mahasiswa (19,44\%) mengatakan bahwa intensitas tentang mengakses informasi dari internet dalam kriteria tidak baik, 0 mahasiswa $(0,00 \%)$ mengatakan bahwa intensitas tentang mengakses informasi dari internet dalam kriteria sangat tidak baik. Hasil ini menunjukkan bahwa mahasiswa masih belum optimal dalam mengakses internet untuk tujuan belajar mata kuliah ilmu pendidikan.

\section{Fasilitas yang Sering Digunakan di Internet}

Berdasarkan jawaban angket pada indikator fasilitas yang sering digunakan di internet oleh masing-masing mahasiswa diperoleh hasil seperti terangkum pada Tabel 5 berikut:

Tabel 5 Fasilitas yang Sering Digunakan di Internet

\begin{tabular}{|c|c|c|c|c|}
\hline No & Rentang Skor & Kategori & Frekuensi & Persentase \\
\hline 1. & $17-20$ & Sangat baik & 10 & $27.78 \%$ \\
\hline 2. & $14-16$ & Baik & 13 & $36.11 \%$ \\
\hline 3. & $11-13$ & Cukup baik & 11 & $30.56 \%$ \\
\hline 4. & $8-10$ & Tidak baik & 2 & $5.56 \%$ \\
\hline 5. & $4-7$ & Sangat tidak baik & 0 & $0.00 \%$ \\
\hline \multicolumn{3}{|c|}{ Jumlah } & 36 & $100.00 \%$ \\
\hline
\end{tabular}

Sumber data: Angket

Berdasarkan Tabel 5 dapat diketahui dari 36 mahasiswa diperoleh keterangan tentang fasilitas yang sering digunakan di internet sebagai berikut : 10 mahasiswa $(27,78 \%)$ terlihat bahwa jawaban mahasiswa tentang fasilitas yang sering digunakan di internet dalam kategori sangat baik, 13 mahasiswa $(36,11 \%)$ terlihat bahwa jawaban mahasiswa tentang fasilitas yang sering digunakan di internet dalam kategori baik, 11 mahasiswa $(30,56 \%)$ terlihat bahwa jawaban mahasiswa tentang fasilitas yang sering digunakan di internet dalam kategori cukup baik, 2 mahasiswa (5,56\%) terlihat bahwa jawaban mahasiswa tentang fasilitas yang sering digunakan di internet dalam kategori tidak baik, 0 mahasiswa $(0,00 \%)$ terlihat bahwa jawaban mahasiswa tentang fasilitas yang sering digunakan di internet dalam kategori sangat tidak baik. Hasil ini menunjukkan bahwa secara umum mahasiswa telah sering menggunakan fasilitas internet yang ada 
hubungannya dengan kegiatan belajar mata kuliah ilmu pendidikan secara baik.

Berdasarkan hasil angket di atas dapat diketahui bahwa pemanfaatan internet pada mata kuliah ilmu pendidikan Jurusan Tarbiyah Fakultas Tarbiyah dan Ilmu Keguruan dapat dilihat pada tabel berikut ini:

Tabel 6 Pemanfaatan Internet pada Mata Kuliah Ilmu Pendidikan Jurusan Tarbiyah Fakultas Tarbiyah dan Ilmu Keguruan (FTIK) IAIN Palangka Raya Tahun 2016

\begin{tabular}{|c|c|c|c|c|}
\hline No & Rentang Skor & Kategori & Frekuensi & Persentase \\
\hline 1. & $85-100$ & Sangat baik & 8 & $22.22 \%$ \\
\hline 2. & $69-84$ & Baik & 18 & $50.00 \%$ \\
\hline 3. & $53-68$ & Cukup baik & 10 & $27.78 \%$ \\
\hline 4. & $37-52$ & Tidak baik & 0 & $0.00 \%$ \\
\hline 5. & $20-36$ & Sangat tidak baik & 0 & $0.00 \%$ \\
\hline \multicolumn{3}{|c|}{ Jumlah } & 36 & $100.00 \%$ \\
\hline
\end{tabular}

Sumber data angket

Tabel 6 di atas menggambarkan bahwa pemanfaatan internet sebagai sumber belajar oleh mahasiswa jurusan tarbiyah Fakultas Tarbiyah dan Ilmu Keguruan (FTIK) IAIN Palangka Raya diketahui bahwa sebanyak 8 orang mahasiswa atau 22,22\% berada paa kategori sangat baik dan sebanyak 18 mahasiswa berada pada kategori baik dan sisanya sebanyak 10 orang atau $27,78 \%$ berada pada kategori cukup baik. Untuk memperjelas hasil angket tentang pemanfaaatan internet pada mata kuliah ilmu pendidikan jurusan Tarbiyah FTIK IAIN Palangka Raya dapat dilihat pada diagram batang di berikut :

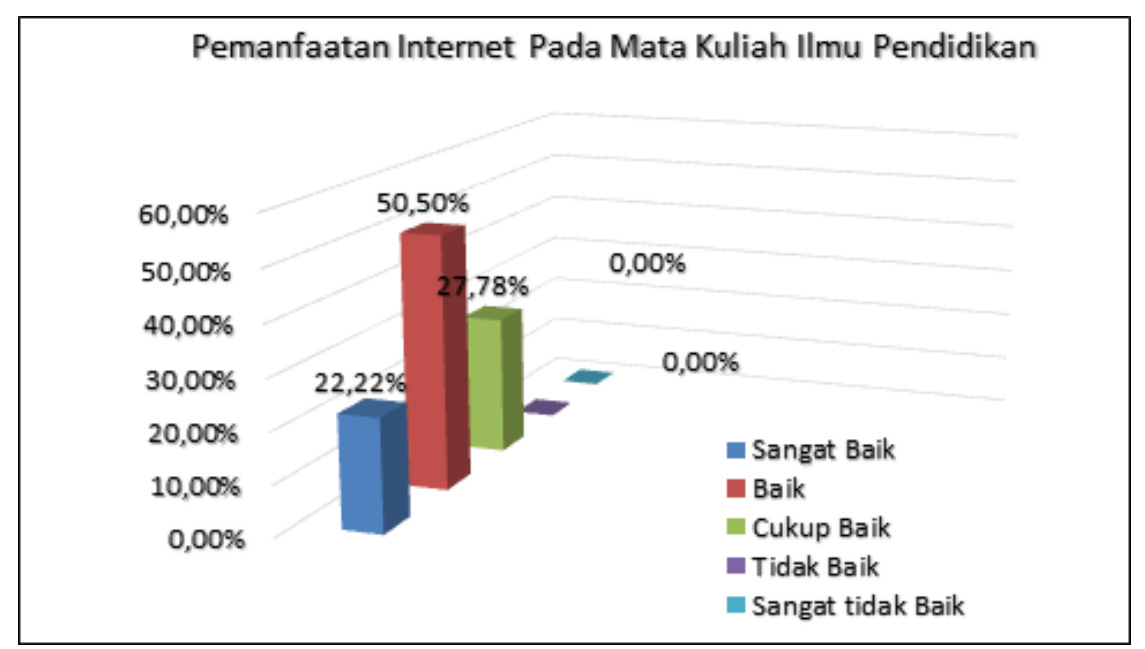

Gambar 1. Gambaran Pemanfaatan Internet pada Matakuliah Ilmu Pendidikan (Sumber data : Angket) 
Berdasarkan diagram batang sebagaimana yang terlihat pada Gambar 1 tersebut dapat diketahui dari 36 mahasiswa diperoleh keterangan tentang tingkat pemanfaatan internet sebagai sumber belajar pada mata kuliah ilmu pendidikan sebagai berikut : 8 mahasiswa (22,22\%) mengatakan bahwa pemanfaatan internet sebagai sumber belajar mata kuliah ilmu pendidikan dalam kriteria sangat baik, 18 mahasiswa (50,00\%) mengatakan bahwa pemanfaatan internet sebagai sumber belajar mata kuliah ilmu pendidikan dalam kriteria baik, 10 mahasiswa (27,78\%) mengatakan bahwa pemanfaatan internet sebagai sumber belajar mata kuliah ilmu pendidikan dalam kriteria cukup baik, 0 mahasiswa (0,00\%) mengatakan bahwa pemanfaatan internet sebagai sumber belajar mata kuliah ilmu pendidikan dalam kriteria tidak baik dan sangat tidak baik. Dari hasil tersebut dapat dijelaskan bahwa secara umum pemanfaatan internet sebagai sumber belajar mata kuliah ilmu pendidikan mahasiswa jurusan Tarbiyah Fakultas Tarbiyah dan Ilmu Keguruan (FTIK) IAIN Palangka Raya baik.

Berdasarkan hasil wawancara dengan mahasiswa maupun dengan dosen pembina mata kuliah ilmu pendidikan pada semester ganjil tahun akademik 2016/2017 dapat dipaparkan sbagai berikut:

\section{Pengenalan Mahasiswa terhadap Internet}

Proses belajar untuk mengenal dan menggunakan internet yang ada di kalangan mahasiswa jurusan Tarbiyah angkatan 2016 yang memprogramkan mata kuliah ilmu pendidikan berdasarkan hasil wawancara didominasi dari sekolah atau guru. Sekolah atau guru merupakan lembaga yang memiliki peran penting dalam memperkenalkan interenet. Kurikulum pendidikan saat ini telah memasukkan Teknologi Informasi dan Komunikasi (TIK) dalam pembelajaran, sehingga peserta didik mendapat pengetahuan tentang internet saat duduk di bangku sekolah menengah. Tidak heran jika saat ini banyak pelajar SMP atau SMA yang mahir dalam menggunakan komputer maupun dalam mengkases internet. Selain itu, tuntutan tugas dari guru saat di sekolah untuk mengakses informasi melalui internet membuat mahasiswa mau tidak mau harus mengenal dan bisa mengoperasikan komputer serta internet.

Hal ini membuktikan bahwa peran sekolah dalam memperkenalkan internet sangat tinggi. Selain peran sekolah, teman merupakan orang yang dekat dan memiliki peran dalam kehidupan kita. Dalam pengenalan internet pun, peran teman juga sangat besar. Bermula dari tidak tahu tentang internet, maka teman akan mengajari kita untuk mengetahui penggunaan internet, baik dari cara mengakses atau mendapatkan informasi serta memberitahukan tentang seluk-beluk internet yang belum kita ketahui. Misalnya pengguna facebook akan membuat suatu tulisan pada wall mereka 
tentang apa yang sedang mereka dipikirkan dari tulisan tersebut maka setiap teman yang sudah berhubungan melalui facebook dapat mengomentari apa yang ditulis tadi.

Kondisi yang sama juga menjadi pertimbangan tersendiri bagi mahasiswa Jurusan Tarbiyah FTIK IAIN Palangka Raya dalam mencari informasi di internet. Tugas-tugas mata kuliah yang diberikan dosen merupakan faktor yang mendorong mahasiswa dalam mengakses internet. Sebagaian besar mahasiswa lebih suka saat mencari informasi yang berkaitan dengan tugas melalui internet dibandingkan mencari tugas melalui buku. Hal tersebut disebabkan kurangnya waktu yang dimiliki responden untuk mencari tugas tersebut melalui buku yang tersedia di perpustakaan. Selain itu, fasilitas internet yang cepat dalam pencarian informasi sangat membantu mahasiswa dalam memanfaatkan waktu yang terbatas untuk mengerjakan tugas-tugas yang lain.

Selain tugas mata kuliah, responden juga menyatakan selain menggunakan internet untuk mencari tugas, mereka juga menggunakan internet untuk mencari informasi yang berhubungan dengan ilmu pengetahuan. Seperti yang kita ketahui, ilmu pengetahuan di dunia setiap hari berkembang mengikuti perkembangan jaman yang ada. Banyaknya penemuan-penemuan di bidang pengetahuan maupun teknologi banyak yang di unggah melalui internet. Tujuannya yaitu agar ilmu pengetahuan yang ada dapat diketahui oleh semua orang. Banyaknya mahasiswa yang mengakses internet untuk mencari tugas mata kuliah menunjukkan adanya relevansi informasi yang dicari dengan maahasiswa Jurusan Tarbiyah FTIK IAIN Palangka Raya. Tingkat relevansi yang dimaksudkan belum merujuk pada kebutuhan perkuliahan.

Analisis terhadap tanggapan para responden menyangkut materi kuliah yang tersedia di internet menurut asal program studi responden juga menunjukkan hasil yang berbeda, dan sangat beragam hasilnya. Dari hasil wawancara memperlihatkan bahwa informasi yang diakses melalui internet berhubungan mata kuliah mahasiswa. Ini artinya, mahasiswa merasa bahwa para dosen mereka memotivasi mahasiswa untuk menggunakan informasi yang ada di internet dalam mendukung kelancaran perkuliahan. Kelancaran mahasiswa dalam mengakses internet didukung oleh banyak faktor. Berdasarkan hasil data yang diperoleh menyatakan bahwa banyak faktor yang mendukung mereka dalam mengakses internet. Faktor tersebut diantaranya yaitu: adanya fasilitas misalnya hotspot di area kampus, adanya tuntutan pencarian tugas mata kuliah serta kebutuhan akan informasi dan pengetahuan baru. Diketahui bahwa semua responden menyatakan internet sangat bermanfaat bagi mereka. Manfaat yang mereka peroleh antara lain: mempermudah pencarian informasi, menambah pengetahuan, berita atau 
informasi yang disajikan selalu diperbarui, sebagai alat komunikasi dan membantu dalam mengerjakan tugas mata kuliah.

\section{Pemanfaatan Internet sebagai Sumber Belajar}

Berdasarkan hasil wawancara, didapatkan berbagai macam jawaban yang dikemukakan responden. Situs yang sering diakses responden yaitu jejaring sosial, google dan yahoo. Jejaring sosial menempati urutan yang paling banyak diakses, jejaring sosial yang diakses meliputi facebook dan twitter. Tingginya akses jejaring sosial disebabkan karena jejaring sosial merupakan media bagi responden untuk mengekspresikan diri mereka. Selain itu, dengan jejaring sosial responden dapat berkomunikasi dengan teman, kerabat maupun orang lain yang baru dikenal. Tidak jarang juga, jejaring sosial ini digunakan untuk sarana bagi pendidik dalam memberikan tugas kepada peserta didik atau mahasiswa.

Selain jejaring sosial, google merupakan situs yang sering diakses. Melalui situs ini, responden dapat mencari berbagai macam informasi dan pengetahuan yang mereka cari. Hanya dengan mengetikkan kata yang dicari pada search engine, maka akan muncul berbagai macam situs yang memuat kata tersebut. Biasanya, responden memanfaatkan google untuk membantu dalam mencari informasi yang berhubungan dengan tugas mata kuliah mereka. Dalam google juga tersedia ruang untuk berkomunikasi melalui layanan gmail. Melalui layanan tersebut, responden dapat mengirimkan email kepada orang lain dan juga berkomunikasi dengan orang lain. Tidak jauh berbeda dengan google, yahoo juga merupakan situs yang banyak diakses responden. Pada umumnya, responden menggunakan situs ini untuk mengirimkan surat melalui email, selain surat juga tugas mata kuliah dikirim melalui email. Situs ini juga memuat berbagai macam informasi, mulai dari hiburan, pengetahuan, teknologi dan masih banyak lagi.

Sebagian besar responden mengemukakan bahwa situs yang sering mereka kunjungi atau akses berhubungan dengan mata kuliah responden. Dari hasil wawancara, dapat dilihat bahwa seluruh responden yaitu menyatakan bahwa situs-situs yang mereka akses berhubungan dengan mata kuliah ilmu pendidikan walaupun ada dosen yang menyarankan sumber dari internet hanya satu referensi untuk makalah kelompok maupun tugas individual. Internet termasuk sumber belajar berbentuk media elektronik. Meskipun ada beberapa responden yang menyatakan internet bukan sumber belajar bagi mereka, namun sebagian besar responden menyatakan internet adalah sumber belajar. Adanya internet, responden merasa lebih mudah dan cepat dalam mendapatkan informasi yang berkaitan dengan mata kuliah khususnya bagi mahasiswa Ilmu Pendidikan Jurusan Tarbiyah FTIK IAIN Palangka Raya. Adapun alasan responden tidak menjadikan internet sebagai

Al-Khwarizmi - 79 
sumber belajar karena responden menganggap bahwa sumber belajar yang utama menurut mereka adalah buku. Hal ini sesuai dengan yang dijelaskan bahwa sumber belajar adalah semua sumber baik berupa data, orang dan wujud tertentu yang dapat digunakan oleh peserta didik dalam belajar, baik secara terpisah maupun secara terkombinasi sehingga mempermudah peserta didik dalam mencapai tujuan belajar atau mencapai kompetensi tertentu.

Selain hal di atas menurut responden mengemukakan bahwa banyak manfaat yang dapat diambil dari penggunaan internet sebagai sumber belajar. Manfaat tersebut yaitu internet dapat membantu responden dalam mencari informasi yang berhubungan dengan tugas mata kuliah, selain itu internet juga merupakan sumber informasi yang setiap hari selalu mengalami pembaruan (up to date). Dengan internet, pengetahuan dan wawasan responden terhadap berbagai hal juga bertambah. Mahasiswa mendapatkan informasi tersebut dengan mendownload melalui internet.

\section{Faktor Pendukung Pemanfaatan Internet sebagai Sumber Belajar}

Berdasarkan hasil wawancara, didapatkan berbagai macam jawaban berkenaan dengan faktor pendukung pemanfaatan internet sebagai sumber belajar. Berikut adalah petikan hasil wawancara dengan responden mengenai faktor pendukung internet sebagai sumber belajar. Faktor-faktor tersebut antara lain :

1. Tuntutan dari dosen untuk memenuhi tugas mata kuliah Tugas mata kuliah yang diberikan oleh dosen menjadikan responden mau tidak mau menggunakan internet. Menurut mahasiswa, internet menyediakan fasilitas informasi yang sangat banyak terutama yang berhubungan dengan mata kuliah mahasiswa Ilmu Pendidikan Jurusan Tarbiyah FTIK IAIN Palangka Raya. Dengan internet, mahasiswa sangat terbantu untuk mengakses informasi. Alasan lain yang menjadi faktor pendorong penggunaan internet sebagai sumber belajar adalah mahasiswa enggan mengunjungi perpustakaan yang menyediakan banyak buku dimana di dalam buku tersebut terdapat informasi yang berhubungan dengan tugas mata kuliah mereka. Mahasiswa lebih senang mengakses internet, karena lebih cepat dan tidak membutuhkan waktu lama untuk mendapatkan informasi yang diinginkan.

2. Sumber belajar yang ada di internet lebih lengkap berbeda dengan buku, internet menyediakan sumber wacana yang lebih lengkap. Buku yang ada hanya menyediakan informasi terntentu sesuai dengan judul buku yang ada. Sedangkan internet menyediakan banyak informasi sebagai sumber belajar sesuai dengan informasi yang dicari. "Sumber informasi dan data yang ada di internet lebih lengkap dibandingkan dengan buku. 
Kalau di buku kita harus membaca satu persatu, tetapi kalau menggunakan internet kita tinggal mencari informasi yang kita cari lalu informasi yang kita butuhkan sudah ada di internet"9

3. Menurut Rinto menambahkan hanya dengan mencari pada search engine, informasi yang kita butuhkan akan ditampilkan dalam internet, mulai dari informasi yang pertama kali diunggah atau yang baru saja diunggah ${ }^{10}$. Dari hasil wawancara ersebut dapat diketahui bahwa dengan internet dapat memperoleh informasi yang ada selalu bertambah dan berkembang, sehingga internet menjadi pilihan sumber belajar yang lengkap.

4. Membantu dalam mendapat referensi mata kuliah

5. Informasi yang ada internet membantu mahasiswa Jurusan Tarbiyah FTIK IAIN Palangka Raya dalam mendapatkan referensi mengenai mata kuliah mereka. Mahasiswa mendapatkan tambahan pengetahuan dengan mengakses internet. Referensi yang mereka dapatkan dapat membantu mahasiswa dalam mengikuti perkuliahan, karena sebelum mengikuti perkuliahan mahasiswa telah mendapatkan informasi yang berkaitan dengan bahan kuliah mereka. Jadi, mahasiswa dapat mengetahui pokok bahasan yang akan dibahas dalam perkuliahan, sehingga mahasiswa dapat mengikuti perkuliahan dengan baik.

6. Mempermudah untuk mengerjakan tugas

7. Internet sangat membantu mahasiswa dalam mengerjakan tugas. Internet menyediakan banyak informasi khususnya yang berkaitan dengan tugas mata kuliah mereka. Namun banyak mahasiswa yang menyalahgunakan penggunaan internet dalam membantu pengerjaan tugas mata kuliah. Sebagian besar mahasiswa hanya mengambil informasi yang berhubungan dengan tugas misalnya, jika mahasiswa mendapat tugas membuat makalah tentang Kurikulum di Indonesia, maka mahasiswa akan mencari makalah yang isinya sama dengan tugas mereka, kemudian mahasiswa hanya mengganti data diri yang ada dengan data diri mereka. "Kalau ada tugas membuat makalah, biasanya saya dan teman-teman mencari di internet. Jika tema makalahnya sama biasanya saya copy paste lalu saya edit sedikit."11

8. Seharusnya mahasiswa dapat memanfaatkan informasi yang ada kemudian mengembangkan sendiri sesuai dengan tugas yang diberikan, sehingga informasi yang ada di internet menjadi sumber tambahan dalam membantu menyelesaikan tugas perkuliahan.

\footnotetext{
${ }^{9}$ Hasil wawancara dengan Detria, Rabu tanggal 14 September 2016

10 Hasil wawancara dengan Rinto, Rabu tanggal 14 September 2016

${ }^{11}$ Hasil wawancara dengan Andi, Senin tanggal 12 September 2016
} 
9. Informasi yang ada lebih jelas dan valid

10. Informasi yang ada di internet setiap hari selalu mengalami pembaruan. Hal tersebut yang mendorong mahasiswa dalam memanfaatkan internet sebagai sumber belajar. "Informasi yang ada di internet biasanya setiap hari ada yang baru sehingga kalau ada materi kuliah yang membutuhkan data yang valid, maka saya akan mencari di internet tentang data dan sumbernya."12 Banyak sumber yang menyatakan bahwa setiap ada informasi yang baru.

11. Lebih cepat dalam pencarian informasi

12. Kecepatan dalam mendapatkan informasi adalah salah satu faktor yang mendukung pemanfaatan internet sebagai sumber belajar. Mahasiswa tidak perlu menghabiskan waktu untuk mencari informasi yang mereka inginkan. "Mencari informasi atau data di internet lebih cepat daripada mencari di buku, waktunya banyak terbuang untuk mencari buku. Kita harus mencari dulu buku yang kita butuhkan, jika tidak ada kita harus beli buku di toko buku."13

13. Sumber pengetahuan lebih lengkap Sumber pengetahuan yang ada di internet lebih lengkap dibandingkan sumber belajar yang lain. Pengetahuan yang ada pun tidak hanya berasal dari dalam negeri melainkan dari berbagai negara yang ada di seluruh belahan dunia. Pengetahuan yang ada pun tidak hanya menggunakan bahasa Indonesia melainkan menggunakan bahasa universal atau bahkan bahasa yang ada di masing-masing negara. "Pengetahuan yang ada di internet sangat lengkap. Informasi atau pengetahuan yang ingin kita cari, dapat kita cari tahu di internet. Kejadian atau peristiwa yang terjadi di dunia dapat degan cepat kita ketahui lewat internet."14 Adanya fasilitas hotspot di kampus Adanya fasiltas yag mendukung mahasiswa dalam mengakses internet di kampus adalah fasilitas hotspot. Fasilitas ini ditujukan untuk memudahkan mahasiswa dalam mengakses internet. Dalam hal ini mahasiswa yang memiliki laptop atau netbook dapat memanfaatkan fasilitas yang ada, bedahalnya dengan mahasiswa yang belum memiliki laptop atau netbook, mereka tidak dapat memanfaatkan fasilitas ini untuk mengakses internet. "Area hotspot yang ada di kampus sangat membantu saya dalam mengakses internet. Saya tidak perlu ke warnet, karena dengan membawa laptop saya bisa mengakses internet di area

\footnotetext{
12 Hasil wawancara dengan Agus, Senin tanggal 12 September 2016

13 Hasil wawancara dengan Hamdi Selasa tanggal 13 September 2016

${ }^{14}$ Hasil wawancara dengan Emi, Rabu tanggal 14 September 2016
} 
hotspot yang dikampus baik dekat atm BRI maupun di corner dekat Mikwa."15

14. Berita yang up to date (terbarukan) pada bagian sebelumnya telah dijelaskan bahwa berita atau informasi yang ada di internet selalu mengalami pembaruan atau selalu up date. Pembaruan tersebut sangat membantu dalam mendapatkan informasi yang aktual dan terpercaya. Sehingga apa yang dicari mahasiswa dalam internet merupakan data atau berita terbaru bukan data lama, karena setiap hari pengetahuan selalu berkembang. Hal itulah yang mendukung mahasiswa memanfaatkan internet sebagai sumber belajar. "Berita-berita yang baru biasanya langsung dirilis di internet, banyak situs yang menayangkan informasi terbaru. Misalnya, peristiwa demo terhadap Ahok di Jakarta langsung dapat diketahui cepat melalui internet."16

15. Biaya lebih murah biaya yang terjangkau merupakan faktor pendukung internet dijadikan sumber belajar. Dikatakan murah karena mahasiswa tidak perlu membayar mahal untuk membeli informasi yang mereka butuhkan. Akan tetapi mereka hanya cukup membayar biaya dalam mengakses internet. Biaya yang mereka keluarkan setiap mengakses dapat dijangkau oleh uang yang mereka miliki. "Kalau mencari informasi dari internet lebih murah, cukup dengan membayar biaya mengakses internet. Jika kita mencari informasi melalui buku, kita harus mengeluarkan biaya yang lebih untuk membeli buku atau untuk biaya transportasi meminjam buku di perpustakaan karena tidak semua buku yang kita cari ada diperpustakaan."17

16. Mudah diakses kemudahan akses internet menjadikan internet sebagai sumber belajar favorit di kalangan mahasiswa. Kemudahan akses ini didukung dengan banyaknya provider yang menyediakan jasa internet. Persaingan dunia telekomunikasi menyebabkan semakin mudahnya orang mengakses internet. Di berbagai tempat saat ini banyak ditemui warung-warung internet yang menyediakan tempat untuk mengakses internet, tidak hanya itu saja adanya fasilitas hotspot juga menyebabkan mahasiswa mendapatkan kemudahan dalam mengakses internet. "Mengakses internet sekarang lebih mudah dan cepat, kita bisa mengakses di warnet, di ponsel atau di area hotspot kampus."18

17. Rasa ingin tahu yang besar menjadi pendorong bagi mahasiswa untuk mengakses internet. Dari internet mahasiswa memperoleh jawaban dari

${ }^{15}$ Hasil wawancara denganSyukri, Rabu tanggal 14 September 2016

${ }^{16}$ Hasil wawancara dengan Lukman, Selasa tanggal 13 September 2016

${ }^{17}$ Hasil wawancara dengan Rinto, Rabu tanggal 14 September 2016

18 Hasil wawancara dengan Fitri, Kamis tanggal 15 September 2016 
rasa keingintahuannya tersebut dan hal itulah yang menyebabkan tingginya mahasiswa dalam memanfaatkan internet sebagai sumber informasi mereka. "Kalau ada informasi baru biasanya saya mencari di internet, misalnya saja saya ingin tahu tentang materi kuliah yang akan dibahas, saya bisa mengakses internet dengan menuls topik yangakan dibahas."19

Kebutuhan akan informasi menjadi kebutuhan yang utama bagi mahasiswa dalam mengakses internet. Kebutuhan tersebut didorong oleh adanya tugas yang diberikan oleh dosen atau kebutuhan untuk mendapatkan pengetahuan baru, sehingga akan lebih mudah didapatkan jika mengaksesnya melalui internet. "Buat saya internet sudah menjadi kebutuhan, apalagi kalalu ada tugas dari dosen, biasanya saya langsung pergi ke warnet."20 Menurut responden, tuntutan dari dosen untuk memenuhi tugas mata kuliah merupakan faktor yang mendukung mahasiswa dalam menggunakan internet sebagai sumber belajar. Dengan adanya tuntutan dosen, mau tidak mau mahasiswa akan mencari informasi melalui berbagai macam sumber belajar salah satunya melalui internet. Untuk saat ini, internet merupakan sumber belajar yang mudah dan cepat untuk digunakan. Mahasiswa lebih mudah mendapatkan informasi yang berkaitan dengan tugas tersebut, karena semua orang tidak terkecuali mahasiswa dapat mengakses melalui internet di mana saja dan kapan saja.

Berbeda dengan sumber belajar berupa buku, jika mahasiswa tidak memiliki buku, maka mereka akan pergi ke perpustakaan untuk meminjuam buku yang berhubungan dengan tugas mereka. Jika buku tersebut tidak ada, maka mereka harus mencari atau bahkan membeli di toko buku. Tidak hanya tuntutan dosen, tetapi karena dalam internet mengandung berbagai macam sumber informasi, maka responden menganggap bahwa internet adalah sumber belajar yang lengkap. Responden sangat terbantu dengan kehadiran internet karena dari internet juga, responden mendapatkan resensi yang berhubungan dengan mata kuliah mereka. Dengan begitu, memudahkan dalam mengerjakan tugas. Informasi yang terkandung dalam internet pun jelas dan valid, biasanya dalam informasi yang diperoleh akan dicantumkan pula penulis dan tahun pembuatannya. Jadi, responden dapat mencari informasi yang terbaru dan lebih lengkap. Kecepatan dalam mengakses informasi merupakan faktor pendukung penggunaan internet sebagai sumber belajar.

\footnotetext{
${ }^{19}$ Hasil wawancara dengan Cahyaning, Kamis tanggal 15 September 2016

${ }^{20}$ Hasil wawancara dengan Lutvia, Jumat tanggal 16 September 2016
} 
Banyaknya warnet, area hotspot di kampus dan fasilitas internet yang disediakan di kampus khususnya kampus IAIN Palangka Raya sangat berperan bagi mahasiswa dalam menggunakan internet. tidak hanya itu, biaya akses yang terjangkau merupakan salah satu faktor pendukung pula. Banyaknya warnet di sekitar kampus yang menawarkan biaya yang murah dalam mengakses internet sangat menguntungkan mahasiswa yang tidak memiliki PC maupun laptop pribadi. Untuk mahasiswa yang memiliki laptop, mereka cukup membawa laptop mereka di area yang dilengkapi fasilitas hotspot. Faktor pendukung yang berasal dari dalam diri responden yaitu adanya kebutuhan dan rasa keingintahuan yang besar mendorong responden untuk menggunakan internet sebagai sumber belajar mereka.

\section{Penutup}

Berdasarkan hasil analisis, diperoleh beberapa kesimpulan sebagai berikut:

1. Pemanfaatan internet berdasarkan hasil angket diketahui bahwa 36 mahasiswa diperoleh keterangan tentang tingkat pemanfaatan internet sebagai sumber belajar pada mata kuliah ilmu pendidikan sebagai berikut : 8 mahasiswa (22,22\%) kriteria sangat baik, 18 mahasiswa (50,00\%) kriteria baik, 10 mahasiswa $(27,78 \%)$ kriteria cukup baik, 0 mahasiswa $(0,00 \%)$ mengatakan bahwa pemanfaatan internet sebagai sumber belajar mata kuliah ilmu pendidikan dalam kriteria tidak baik dan sangat tidak baik. Dari hasil tersebut dapat dijelaskan bahwa secara umum pemanfaatan internet sebagai sumber belajar mata kuliah ilmu pendidikan mahasiswa jurusan Tarbiyah Fakultas Tarbiyah dan Ilmu Keguruan (FTIK) IAIN Palangka Raya baik.

2. Alasan mahasiswa Jurusan Tarbiyah FTIK IAIN Palangka Raya dalam memanfaatkan internet sebagai sumber belajar adalah karena internet dapat membantu mahasiswa dalam mencari informasi dan tugas matakuliah Ilmu Pendidikan. Apabila tidak ada tugas, mahasiswa sebagian besar memanfaatkan internet untuk mengakses media sosial seperti facebook, twitter, youtube, dan lainnya.

3. Faktor pendukung pemanfaatan internet sebagai sumber belajar mahasiswa antara lain tuntutan dari dosen untuk memenuhi tugas mata kuliah Ilmu Pendidikan, sumber belajar yang ada di internet lebih lengkap, membantu dalam mendapat resensi mata kuliah, mempermudah untuk mengerjakan tugas, informasi yang ada lebih jelas dan valid, lebih cepat dalam pencarian informasi, sumber pengetahuan lebh lengkap, adanya fasilitas hotspot di kampus, berita yang up to date/baru, biaya lebih murah, mudah diakses, keingintahuan dan kebutuhan. 
Berdasarkan temuan yang ada kiranya ada beberapa hal yang bisa disarankan untuk dilakukan diantaranya:

1. Agar pihak IAIN Palangka Raya memperhatikan bahwa semakin tingginya tuntutan akan informasi oleh mahasiswa Jurusan Tarbiyah FTIK IAIN Palangka Raya dapat diantisipasi dengan cara menyediakan layanan internet di gedung perkuliahan FTIK IAIN Palangka Raya.

2. Agar pihak IAIN Palangka Raya memperluas fasilitas hotspot area di kampus sehingga mahasiswa dapat lebih mudah mengakses internet.

\section{Daftar Pustaka}

Idris, Fazilah. 'Jurnal Bahasa (Pembelajaran Bahasa)'. Makalah Internet Dan Belajar, 2010.

Murshid, Nafisah Binti. 'Hubungan Penggunaan Media Komputer Berbasis Internet Sebagai Sumber Belajar Dengan Hasil Belajar Mahasiswa Malaysia Di Universitas Negeri Semarang Tahun Akademik 2000/2001'. Jurusan Kurikulum Teknologi Pendidikan Fakultas Ilmu Pendidikan Universitas Negeri Semarang, 2001.

Parji. Strategi Pembelajaran Pendidikan Moral Pada Era Teknologi Informasi. Madiun, 2011.

'Pengertian Jaringan Internet', 2016. www.seputar.com.2016/02/9pengertian-jaringan-internet-menurut-para-ahli.html.

Sadirman, Arief S. Media Pendidikan: Pengertian, Pengembangan Dan Pemanfaatannya. Jakarta: Raja Grafindo Persada, 1993.

Surya, Mohammad H. 'Tantangan Dan Problema Pendidikan Memasuki Milenium Ketiga'. Ilmiah Wahana, 2010.

Sutedjo, Budi Oetomo Dharma. E-Education Konsep, Teknologi Dan Aplikasi Internet Pendidikan. Yogyakarta: Andi Yogyakarta, 2002. 